\title{
EFFECT OF DIFFERENT MEALYBUG SPECIES AS PREYS ON SOME BIOLOGICAL CHARACTERS AND PREDACEOUS EFFICIENCY OF THE COCCINELLID PREDATOR Rodolia cardinalis (Mulsant) (Coleoptera: Coccinellidae) UNDER LABORATORY CONDITIONS \\ Ghanim, A. A. * ; A. H. Abdel-Salam *; H. A. Elkady **; M. E. El-Nagar ${ }^{\star \star *}$ and Hagar S. S. Awadalla ${ }^{* *}$ \\ * Economic Entomology Dept. Fac. of Agric.. Mans. Univ., Egypt. \\ ** Economic Entomology Dept. Fac. of Agric. Damietta Univ., Egypt. \\ *** Agric. Res. Center, Giza, Egypt.
}

\begin{abstract}
Laboratory experiments were carried out to study the influence of different mealybug species as preys on the biological aspects of Rodolia cardinalis (Mulsant) in the insectary of the Economic Entomology, Faculty of agriculture, Mansoura University.

The larval stage of the predator $R$. cardinalis when reared at $24 \pm 1^{\circ} \mathrm{C}$ and fed on the third nymphal instars of Icerya purchase Mask., Icerya aegyptiaca Douglas and Icerya seychellarum (Westwood) lasted an average of $14.5 \pm 0.60,11.8 \pm 0.34$ and $16.6 \pm 0.55$ days, respectively.

The average of the total consumption for larval instars at $24 \pm 1^{\circ} \mathrm{C}$ and fed on $I$. purchasi, I. aegyptiaca and I. seychellarum as preys reached $68.90 \pm 4.01,60.50 \pm 2.18$ and $42.65 \pm 1.77$ individuals. Meanwhile, results indicated that, the highest total consumption for the predator larvae during its larval stages when fed on I. purchasi followed by $I$. aegyptiaca and I. seychellarum with significant differences.

The calculated biomass from (carbohydrates, lipids and protein) consumed by a larva when fed on I. purchasi, I. aegyptiaca and I. seychellarum reached an average of (88.88, 85.44 and $49.61 \mathrm{mg}),(80.47,77.44$ and $45.98 \mathrm{mg})$ and (49.90, 49.05 and $28.15 \mathrm{mg}$ ), respectively.

The adult longevity for female and male when reared at $24 \pm 1^{\circ} \mathrm{C}$ and reared on the third nymphal instar of $I$. purchasi, I. aegyptiaca and $I$. seychellarum lasted an average of (40.5 \pm 2.25 and $26.8 \pm 1.72$ days), (46.4 \pm 2.12 and $29.0 \pm 2.09$ days) and $(32.5 \pm 2.60$ and $20.8 \pm 1.8$ days), respectively.

The average of the total consumption for adult female reached $263.2 \pm 11.25$, $328.2 \pm 10.90$ and $208.7 \pm 6.88$ individuals/ female when fed on I. purchasi, I. aegyptiaca and $I$. seychellarum, respectively, with highly significant differences.

The calculated biomass from (carbohydrates, lipids and protein) consumed by one predator female during its longevity reached (339.53, 326.37 and $189.5 \mathrm{mg}),(436.51$, 420.10 and $249.43 \mathrm{mg}$ ) and $(244.18,240.01$ and $137.74 \mathrm{mg}$ ) when fed on I. purchasi, $I$. aegyptiaca and $I$. seychellarum, respectively, where for the adult male reached (167.57, 161.08 and $93.53 \mathrm{mg}),(193.91,186.62$ and $110.81 \mathrm{mg})$ and $(116.65,114.66$ and $65.80 \mathrm{mg}$ ), respectively.

The highest total consumption for adult female recorded during the ovipostion period especially, when reared on I. aegyptiaca (289.0 \pm 10.53 individuals/ female) and resulting, the number of deposited eggs/ female was the highest (354.30 \pm 19.90 eggs/ female), it could be concluded that the best mealybug species for rearing $R$. cardinalis was $I$. aegyptiaca because the female layed 354.30 eggs/female.
\end{abstract}


Ghanim, A. A. et al.

\section{INTRODUCTION}

Rodolia cardinalis (Mulsant) (Coleoptera: Coccinellidae) is an important coccinellid predator feeding on mealybug species (Hamed and Saad 1989, Lehane 1998, Ibrahim 2005 and Awadalla 2010). The effect of temperature and mealybug species as prey types on the developmental time, fecundity and the other biological characters were studied by several investigators in different parts of the world (Khalaf 1987, Ragab 1995, Causton et al. 2004, Grafton et al. 2005, Ghanim et al. 2006 and Awadalla 2010).

For integrated pest management program needs the evaluation of the definite role of the natural enemies of these insect pests and knowledge of the population relationships of the insect host and their natural more ecological and biological informations.

A few information is available on the influence of different mealybug species as preys on the biological aspects and on predaceous efficiency of the coccinellid predator $R$. cardinalis.

Therefore, the aim of the present work is to study Influence of different mealybug species as preys on the biological characters and predaceous efficiency of the predator $R$. cardinalis

\section{MATERIAL AND METHODS}

Laboratory experiments were carried out under constant temperature of $24 \pm 1^{\circ} \mathrm{C}$ and $70 \pm 5 \%$ relative to study the influence of different mealybug species as preys on some biological aspects of the coccinellid predator Rodolia cardinalis (Mulsant). The experiments were carried out in the insectary of the Economic Entomology Department, Faculty of Agriculture, Mansoura University.

To obtain a culture from the predator $R$. cardinalis a large numbers in the pupal stage were collected from ficus, Ficus nitida thunb., guava, Psidium guava L., persimmon, Diospyros kaki L. and citrus trees which were found to be a heavily infested with the three mealybug species namely Icerya purchasi Maskell, Icerya aegyptiaca (Douglas) and Icerya seychellarum (westwood) and transferred to the laboratory until emergence of the adults.

To explain the difference in various biological characters of the predator R. cardinalis, chemical analysis was carried out by using one gram of living insects of I. purchasi, I. aegyptiaca and I. seychellarum to determine the total carbohydrates, protein and lipids by using the method of Hedge and Hofreiter (1962), Jones et al., (1991) and A.O.A.C. (1984), respectively.

The total carbohydrates, protein and lipids per individual from the different preys were obtained by dividing these amounts per gram by the individual number representing this gram from each mealybug species. Then the average consumption from these components by the different larval instars and the adult stage of the predator were calculated. 


\section{RESULTS AND DISCUSSION}

As shown in Table (1) the larval stage of the predator $R$. cardinalis when reared at $24 \pm 1^{\circ} \mathrm{C}$ and fed on the third nymphal instars of $l$. purchasi, $I$. aegyptiaca and $I$. seychellarum lasted $14.5 \pm 0.60,11.8 \pm 0.34$ and $16.6 \pm 0.55$ days, respectively. Statistical analysis indicated a significant differences on the larval instars of the predator when fed on different mealybug species.

The obtained results illustrated in Table (1) showed that the average of the total consumption during the larval instars when reared on different mealybug species as preys at $24 \pm 1^{\circ} \mathrm{C}$ as well as the calculated biomass from carbohydrates, lipids and protein consumed by one predator during its larval instars.

Table (1): Influence of mealybug species on the duration period of larval instars and predaceous efficiency of $\boldsymbol{R}$. cardinalis when fed on the third nymphal instar of the mealybug species under laboratory conditions of $24 \pm 1^{\circ} \mathrm{C}$ and $70 \pm 5 \%$ R.H.

\begin{tabular}{|c|c|c|c|c|c|c|c|}
\hline \multirow[t]{2}{*}{$\begin{array}{l}\text { Larval } \\
\text { instars }\end{array}$} & \multirow[t]{2}{*}{ Mealybug sp. } & \multirow{2}{*}{$\begin{array}{c}\text { Average } \\
\text { duration } \\
\text { (days) }\end{array}$} & \multirow{2}{*}{$\begin{array}{c}\text { Daily } \\
\text { average } \\
\text { consumption }\end{array}$} & \multirow{2}{*}{$\begin{array}{c}\text { Total mean } \\
\text { consumption }\end{array}$} & \multicolumn{3}{|c|}{$\begin{array}{c}\text { Av. Weight of the main } \\
\text { components consumed / } \\
\text { larvae (mg.) }\end{array}$} \\
\hline & & & & & Carbohydrates & Lipids & protein \\
\hline \multirow[t]{3}{*}{$1^{\text {st }}$} & I. purchasi & $\begin{array}{c}4.0 \pm \\
0.34 \mathrm{~b}\end{array}$ & 2.05 & $\begin{array}{l}8.20 \pm \\
1.09 a\end{array}$ & 10.58 & 10.17 & 5.90 \\
\hline & 1. egyptiaca & $\begin{array}{l}3.3 \pm \\
0.31 \mathrm{~b}\end{array}$ & 2.58 & $\begin{array}{c}8.4 \pm \\
0.96 a\end{array}$ & 11.17 & 10.75 & 6.38 \\
\hline & I. seychellarum & $\begin{array}{l}5.1 \pm \\
0.34 a\end{array}$ & 0.54 & $\begin{array}{l}2.75 \pm \\
0.31 b\end{array}$ & 3.22 & 3.16 & 1.82 \\
\hline \multirow[t]{3}{*}{$2^{\text {nd }}$} & I. purchasi & $\begin{array}{c}3.4 \pm \\
0.23 a\end{array}$ & 3.21 & $\begin{array}{c}10.90 \pm \\
1.31 \mathrm{a}\end{array}$ & 14.06 & 13.52 & 7.85 \\
\hline & I. egyptiaca & $\begin{array}{l}3.1 \pm \\
0.23 a\end{array}$ & 3.46 & $\begin{array}{c}10.55 \pm \\
0.91 \mathrm{a}\end{array}$ & 14.03 & 13.50 & 8.02 \\
\hline & 1. seychellarum & $\begin{array}{l}3.7 \pm \\
0.23 a\end{array}$ & 2.05 & $\begin{array}{l}7.60 \pm \\
0.50 \mathrm{~b}\end{array}$ & 8.89 & 8.74 & 5.02 \\
\hline \multirow[t]{3}{*}{$3^{\text {rd }}$} & I. purchasi & $\begin{array}{l}2.5 \pm \\
0.23 a\end{array}$ & 5.22 & $\begin{array}{c}12.80 \pm \\
1.69 \mathrm{a}\end{array}$ & 16.51 & 15.87 & 9.22 \\
\hline & I. egyptiaca & $\begin{array}{l}2.3 \pm \\
0.22 \mathrm{a}\end{array}$ & 5.62 & $\begin{array}{c}12.65 \pm \\
1.05 \mathrm{a}\end{array}$ & 16.82 & 16.19 & 9.61 \\
\hline & I. seychellarum & $\begin{array}{l}2.6 \pm \\
0.23 a\end{array}$ & 3.14 & $\begin{array}{l}8.00 \pm \\
0.79 b\end{array}$ & 9.36 & 9.20 & 5.28 \\
\hline \multirow[t]{3}{*}{$4^{\text {th }}$} & I. purchasi & $\begin{array}{c}4.2 \pm \\
0.35 \mathrm{~b}\end{array}$ & 8.81 & $\begin{array}{l}37.0 \pm \\
4.46 \mathrm{a}\end{array}$ & 47.73 & 45.88 & 26.64 \\
\hline & I. egyptiaca & $\begin{array}{l}3.2 \pm \\
0.35 c\end{array}$ & 9.03 & $\begin{array}{l}28.9 \pm \\
2.71 b\end{array}$ & 38.44 & 36.99 & 21.96 \\
\hline & I. seychellarum & $\begin{array}{l}5.2 \pm \\
0.33 a\end{array}$ & 4.72 & $\begin{array}{c}24.30 \pm \\
1.62 \mathrm{c}\end{array}$ & 28.43 & 27.95 & 16.04 \\
\hline \multirow[t]{3}{*}{ Total } & I. purchasi & $\begin{array}{l}14.5 \pm \\
0.60 \mathrm{~b}\end{array}$ & 4.90 & $\begin{array}{c}68.90 \pm \\
4.01 \mathrm{a}\end{array}$ & 88.88 & 85.44 & 49.61 \\
\hline & I. egyptiaca & $\begin{array}{l}11.8 \pm \\
0.34 \mathrm{c}\end{array}$ & 5.15 & $\begin{array}{c}60.50 \pm \\
2.48 b\end{array}$ & 80.47 & 77.44 & 45.98 \\
\hline & I. seychellarum & $\begin{array}{l}16.6 \pm \\
0.55 a\end{array}$ & 2.60 & $\begin{array}{c}42.65 \pm \\
1.77 \mathrm{c}\end{array}$ & 49.90 & 49.05 & 28.15 \\
\hline
\end{tabular}

Means followed by the same letters in a column for each larval instar are not significantly differences at $\mathbf{0 . 0 5}$ level of probability (Duncan's Multiple Range Test).

As a conclusion, the average of the total consumption for the total larval instars when fed on I. purchasi, I. aegyptiaca and I. seychellarum as preys reached $68.90 \pm 4.01,60.50 \pm 2.18$ and $42.65 \pm 1.77$ individuals/ predator larva. Meanwhile, results indicated that, the total consumption for the 
Ghanim, A. A. et al.

predator larvae when fed on I. purchasi followed by $I$. aegyptiaca and $I$. seychellarum showed significant differences. The calculated biomass from (carbohydrates, lipids and protein) consumed by one predator larva when fed on $I$. purchasi, I. aegyptiaca and $I$. seychellarum reached an average of (88.88, 85.44 and $49.61 \mathrm{mg}),(80.47,77.44$ and $45.98 \mathrm{mg})$ and $(49.90,49.05$ and $28.15 \mathrm{mg}$ ), respectively.

Data illustrated in Fig. (1) showed that the percentage of total consumption during the four larval instars when fed on three mealybug species. It can be noticed that, the fourth larval instar was the highest percentage of the total consumption and reached 53.76, 47.77 and $56.97 \%$ when fed on I. purchasi, I. aegyptiaca and I. seychellarum as preys, respectively.

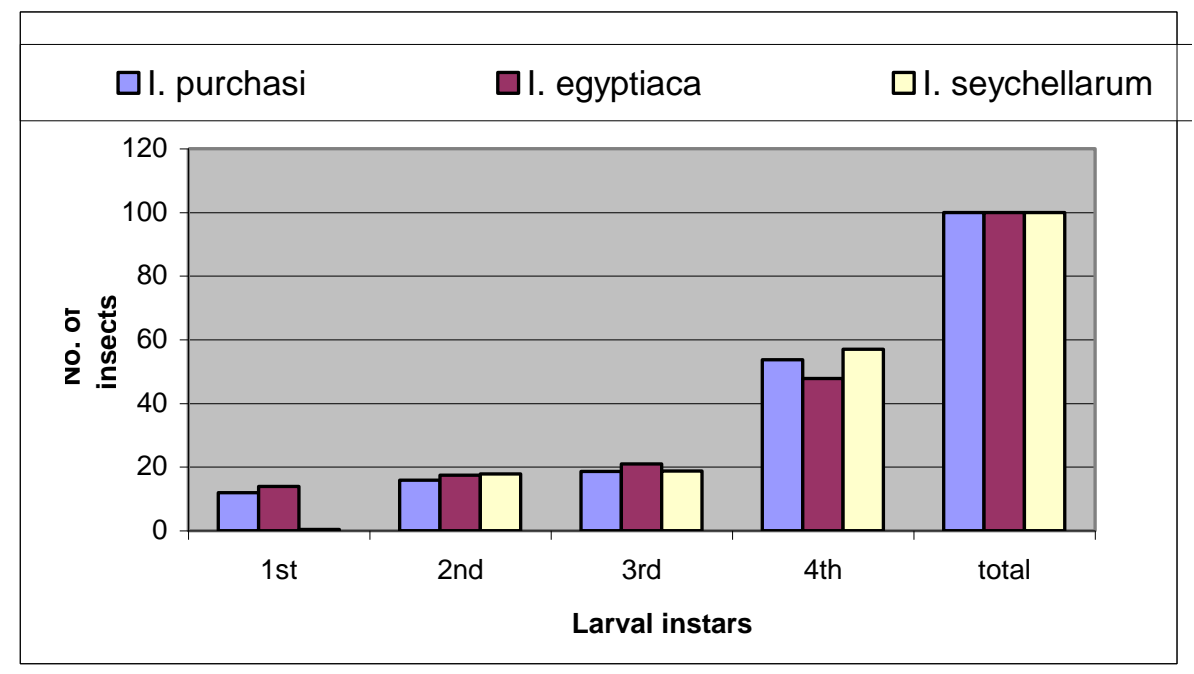

Fig. (1): The percentage of the total consumption during fourth larval instars when reared at $24 \pm 1^{\circ} \mathrm{C}$ and fed on three mealybug species as preys

The obtained results in Table (2) showed that, the adult longevity for female and male when reared on the third nymphal instar of $I$. purchasi, $I$. aegyptiaca and $I$. seychellarum lasted an average of $(40.5 \pm 2.25$ and $26.8 \pm 1.72)$, (46.4 \pm 2.12 and $29.0 \pm 2.09)$ and (32.5 \pm 2.60 and $20.8 \pm 1.8$ days), respectively. Statistical analysis showed significant differences on the ovipositional periods as well as the adult longevity for female and male when fed on different mealybug species.

Data represented in Table (2) showed that the average of the total consumption during the ovipositional period, the number of deposited eggs per female and also, the total consumption for adult male. Moreover, the calculated biomass from carbohydrates, lipids and protein consumed by one adult female during its oviposition periods or one adult male during its longevity. 
Table (2): Influence of prey species on the ovipositional period, predaceous efficiency and fecundity of $\boldsymbol{R}$. cardinalis adults reared on the third nymphal instar of the mealybug species under laboratory conditions of $24 \pm 1^{\circ} \mathrm{C}$ and $70 \pm 5 \%$ R.H.

\begin{tabular}{|c|c|c|c|c|c|c|c|c|}
\hline \multirow{2}{*}{$\begin{array}{c}\text { Biological } \\
\text { aspects }\end{array}$} & \multirow[t]{2}{*}{ Temp. } & \multirow{2}{*}{$\mid \begin{array}{l}\text { Period } \\
\text { (days) }\end{array}$} & \multirow{2}{*}{$\begin{array}{c}\text { Daily } \\
\text { average } \\
\text { consumptio } \\
\mathbf{n}\end{array}$} & \multirow{2}{*}{$\begin{array}{c}\text { Total } \\
\underset{n}{\text { consumptio }}\end{array}$} & \multirow{2}{*}{$\begin{array}{c}\text { Fecun } \\
\text { dity }\end{array}$} & \multicolumn{3}{|c|}{$\begin{array}{l}\text { Average weight of the } \\
\text { main components } \\
\text { consumed / adult (mg.) }\end{array}$} \\
\hline & & & & & & $\begin{array}{c}\text { Carbohy } \\
\text { drates }\end{array}$ & Lipids & $\underset{n}{\text { protei }}$ \\
\hline \multirow{3}{*}{\begin{tabular}{|l|} 
Pre- \\
oviposition \\
period
\end{tabular}} & I. purchasi & $\begin{array}{c}3.8 \pm \\
0.34 b\end{array}$ & 7.79 & $\begin{array}{l}29.6 \pm \\
2.11 \mathrm{a}\end{array}$ & & 38.18 & 36.70 & 21.31 \\
\hline & I. egyptiaca & \begin{tabular}{|l|}
$3.1 \pm$ \\
$0.31 b$
\end{tabular} & 8.26 & $\begin{array}{c}25.6 \pm \\
1.54 \mathrm{ab}\end{array}$ & & 34.05 & 32.77 & 19.46 \\
\hline & \begin{tabular}{|l|}
. \\
seychellarum
\end{tabular} & \begin{tabular}{|c|}
$4.6 \pm$ \\
$0.43 a$
\end{tabular} & 5.20 & $\begin{array}{l}23.9 \pm \\
1.95 b\end{array}$ & & 27.96 & 27.49 & 15.77 \\
\hline \multirow[t]{3}{*}{$\begin{array}{l}\text { Ovipostion } \\
\text { period }\end{array}$} & 1. purchasi & \begin{tabular}{|l|}
$33.8 \pm$ \\
$2.21 b$ \\
\end{tabular} & 6.57 & $\begin{array}{l}222.2 \pm \\
12.08 b\end{array}$ & $\begin{array}{c}323.3 \pm \\
19.24 \\
\end{array}$ & 286.64 & 275.53 & 159.98 \\
\hline & I. egyptiaca & $\begin{array}{l}40.3 \pm \\
2.04 \mathrm{a}\end{array}$ & 7.17 & $\begin{array}{l}289.0 \pm \\
10.83 a\end{array}$ & \begin{tabular}{|l|}
354.30 \\
\pm 19.90
\end{tabular} & 384.37 & 369.92 & 219.64 \\
\hline & seychellarum & $\begin{array}{c}25.0 \pm \\
2.7 c\end{array}$ & 4.12 & $\begin{array}{l}175.4 \pm \\
8.34 c\end{array}$ & $\begin{array}{c}205.3 \pm \\
13.60\end{array}$ & 205.22 & 201.71 & 115.76 \\
\hline \multirow[t]{3}{*}{$\begin{array}{l}\text { Inter- } \\
\text { ovipostion }\end{array}$} & I. purchasi & \begin{tabular}{|c|}
$2.9 \pm$ \\
$0.38 a$ \\
\end{tabular} & 3.93 & $\begin{array}{l}11.4 \pm \\
1.25 \mathrm{~b} \\
\end{array}$ & & 14.71 & 14.14 & 8.21 \\
\hline & I. egyptiaca & $\begin{array}{c}3.0 \pm \\
0.38 \mathrm{a} \\
\end{array}$ & 4.53 & $\begin{array}{l}13.6 \pm \\
1.34 a \\
\end{array}$ & & 18.09 & 17.41 & 10.34 \\
\hline & \begin{tabular}{|l|} 
seychellarum \\
\end{tabular} & \begin{tabular}{|c|}
$3.0 \pm$ \\
$0.38 \mathrm{a}$ \\
\end{tabular} & 3.13 & $\begin{array}{c}9.4 \pm \\
1.01 \mathrm{c} \\
\end{array}$ & & 10.00 & 10.81 & 6.20 \\
\hline \multirow{3}{*}{$\begin{array}{l}\text { Adult } \\
\text { longevity } \\
\text { female }\end{array}$} & I. purchasi & \begin{tabular}{|l|}
$40.5 \pm$ \\
$2.25 b$ \\
\end{tabular} & 6.50 & $\begin{array}{l}263.2 \pm \\
11.25 b \\
\end{array}$ & & 339.53 & 326.37 & 189.5 \\
\hline & 1. egyptiaca & $\begin{array}{l}46.4 \pm \\
2.12 \mathrm{a}\end{array}$ & 7.07 & $\begin{array}{l}328.2 \pm \\
10.90 \mathrm{a}\end{array}$ & & 436.51 & 420.10 & 249.43 \\
\hline & \begin{tabular}{|c|} 
I. \\
seychellarum \\
\end{tabular} & \begin{tabular}{|c|}
$32.5 \pm$ \\
$2.6 c$ \\
\end{tabular} & 4.16 & $\begin{array}{c}208.7 \pm \\
6.88 c \\
\end{array}$ & & 244.18 & 240.01 & 137.74 \\
\hline \multirow{3}{*}{$\begin{array}{c}\text { Adult } \\
\text { Iongevity } \\
\text { male }\end{array}$} & I. purchasi & \begin{tabular}{|l|}
$26.8 \pm$ \\
$1.72 b$ \\
\end{tabular} & 4.85 & $\begin{array}{l}129.9 \pm \\
7.79 b\end{array}$ & & 167.57 & 161.08 & 93.53 \\
\hline & I. egyptiaca & $\begin{array}{l}29.0 \pm \\
2.09 a \\
\end{array}$ & 5.03 & $\begin{array}{c}145.8 \pm \\
6.84 a \\
\end{array}$ & & 193.91 & 186.62 & 110.81 \\
\hline & \begin{tabular}{c|} 
I. \\
seychellarum
\end{tabular} & \begin{tabular}{|c|}
$20.8 \pm$ \\
$1.8 c$
\end{tabular} & 3.32 & $\begin{array}{l}99.7 \pm \\
6.79 c\end{array}$ & & 116.65 & 114.66 & 65.80 \\
\hline
\end{tabular}

Means followed by the same letters in a column for each period are not significantly differences at $\mathbf{0 . 0 5}$ level of probability (Duncan's Multiple Range Test).

As a conclusion, the average of the total consumption for adult female reached $263.2 \pm 11.25,328.2 \pm 10.90$ and $208.7 \pm 6.88$ individuals/ female when fed on $I$. purchasi, I. aegyptiaca and $I$. seychellarum, respectively, with highly significant differences. On the other hand, results showed that, the highest total consumption for adult female recorded during the ovipostion period especially, when fed on I. aegyptiaca $(289.0 \pm 10.53$ individuals/ female) and resulting, the number of deposited eggs/ female was the highest (354.30 \pm 19.90 eggs/ female). Meanwhile, the calculated biomass from (carbohydrates, lipids and protein) consumed by one predator female during its longevity reached $(339.53,326.37$ and $189.5 \mathrm{mg}),(436.51,420.10$ and $249.43 \mathrm{mg})$ and $(244.18,240.01$ and $137.74 \mathrm{mg})$ when fed on $I$. 
Ghanim, A. A. et al.

purchasi, I. aegyptiaca and I. seychellarum, respectively, where for the adult male reached $(167.57,161.08$ and $93.53 \mathrm{mg}),(193.91,186.62$ and 110.81 $\mathrm{mg})$ and $(116.65,114.66$ and $65.80 \mathrm{mg})$, respectively

Data illustrated in Fig. (2) showed the percentage of the total consumption during female ovipositional periods when fed on the third nymphal instar of $I$. purchasi, I. aegyptiaca or I. seychellarum at $24 \pm 1^{\circ} \mathrm{C}$. It can be noticed that, the highest percentage of consumption recorded during oviposition period and reached $84.42,88.05$ and $84.05 \%$ on the three mealybug species, respectively.

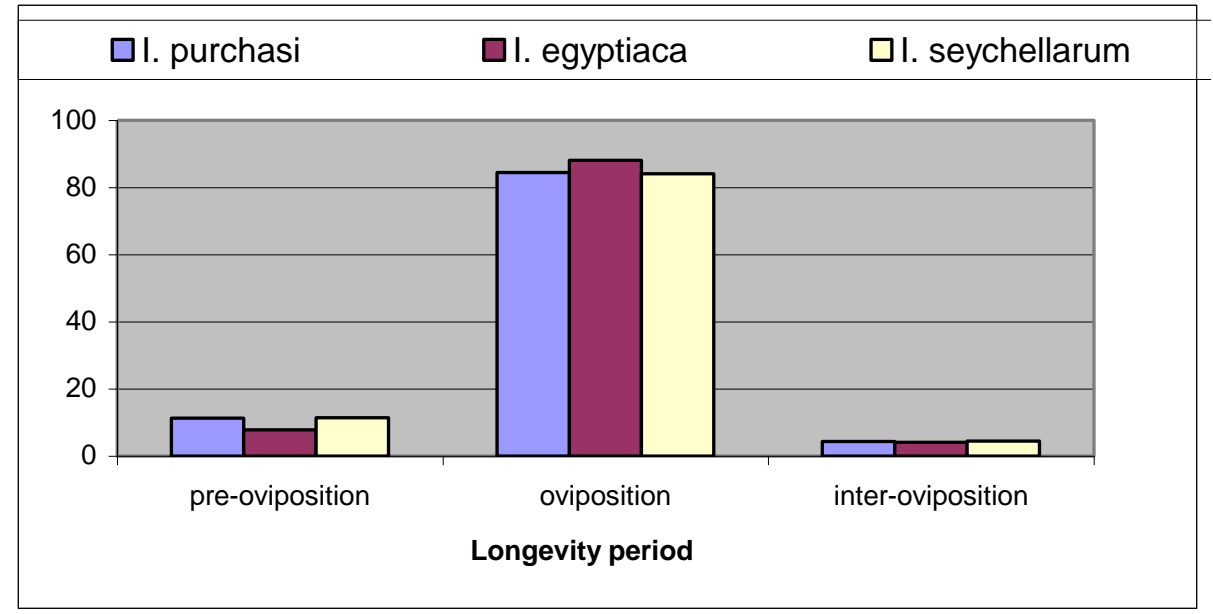

\section{Fig. (2): The percentage of total consumption during female Ovipositional periods when reared at $24 \pm 1^{\circ} \mathrm{c}$ and fed on different mealybug species.}

These results are in agreement with those of Matsuka and Watanabe (1981), Hamed and Saad (1989), Ragab (1995) and Hamed and Chemsedine (2001). The adult females of vedalia beetles which fed on adults of Icerya scales in a Petri dish at $25^{\circ} \mathrm{C}$ produce an average of 365 eggs during their adult life span of 29.4 days, including 3.7 days of pre-oviposition. The average developmental period (egg to adult) was 19.7 days (Matsuka and Watanabe, 1981). Meanwhile, Hamed and Saad (1989) reported that, the longevity of females and males was comparatively shorter in association with I. seychellarum. Moreover, Ragab (1995) indicated that the fecundity of $R$. cardinalis females was not affected by the prey consumed as adults, and although the longevity of males and females was shorter in associated with $I$. purchasi. This difference was not significant. Moreover, Awadalla (2010) suggested that, the survival percentage of $R$. cardinalis immature stages was the highest rates when the predator reared on I. aegyptiaca followed by $I$. purchasi and I. seychellarum. According to the predaceous efficiciency affected by the prey types the obtained results are in agreement with those obtained by Mousa (1992), Ghanim and El Adl (1987 a,b and c) on C. septempunctata, Cy. Vicina isis, Cy. Vicina nilotica and C. undecimpunctata. 
They indicated that, the prey type effected greatly the duration, feeding capacity of larval stage as well as fecundity and longevity of the adult stage of the predators.

\section{REFERENCES}

A.O.A.C. (1984) "Official methods of Analysis" $13^{\text {th }}$ Ed. Published by the Association of Official Analytical chemists, Washington. Dc. U.S.A

Awadalla, Hagar S. S. (2010): Studies on biological and life tables parameters of certain predacious insects which associated with some mealybugs. M. Sc. Thesis, Fac. Agric., Mansoura Univ. pp. 125.

Causton, C. E.; Lincango, M. P. and Poulsom, T. G. A. (2004). Feeding range studies of Rodolia cardinalis (Mulsant), a candidate biological control agent of Icerya purchasi Maskell in the Galapagos Islands. Biological control, 29(3): 315-325.

Ghanim, A. A.; El-Serafi, H. A. K. and Mohamed, N. E. (2006). Effect of mealybug species as preys on the developmental time, feeding capacity and fecundity of vedalia beetle, Rodolia cardinalis (Mulsant) (Coleoptera: Coccinellidae) under laboratory conditions. J. Agric. Sci. Mansoura Univ., 31(3): 1679-1687.

Ghanim, A.A. and El-Adl, M.A. (1987a): Laboratory studies on the feeding capacity, development and fecundity of Chrysopa septempunctata Wesm. (Chrysopidae: Neuroptera). J. Agric. Soci. Mansoura Univ. 12(4): 1352-1357.

Ghanim, A.A. and El-Adl, M.A. (1987b): Evaluation of predation activity and fecundity of the coccinellids, Cydonia (= Chilomones) vicina isis $\mathrm{cr}$; Cydonia $(=$ Chilomones $)$ vicina nilotica Muls. And Coccinella undecimpunctata L. in Mansoura region, Egypt. J. Agric. Sci. Mansoura Univ. 12(4): 993-1000.

Ghanim, A.A. and El-Adl, M.A. (1987c). The feeding capacity and duration of the larval instars of three ladybird beetles fed on different aphid apecies under natural weather conditions at Mansoura, Egypt. J. Agric. Sci. Mansoura Univ. 12(4): 981-987.

Grafton, E. E.; Gu, P. and Montez, G. H. (2005). Effect of temperature on development of vedalia beetle, Rodolia cardinalis (Mulsant). Biological control, 32: 473-478.

Hamed, A. R. and Saad, B. (1989). Adaptation of Rodolia cardinalis (Mulsant) (Coleoptera: Coccinellidae) to Icerya aegyptiaca (Douglas) and Icerya seychellarum (Westwood) (Hom., Margrodidae). Proc. First Int. Conf. Econom. Entomol., 11: 33-36.

Hamed, T. and Chemsedine, M. (2001). Assessment of temperature effects on the development and fecundity of Pllus mediterraneus (Coleoptera: Coccinellidae) and consumption of Saissetia oleae eggs (Homoptera: Coccidae). J. Appl. Ent., 125(9):527-531.

Hedge, I.E. and Hofreiter, B. T. (1962). "Carboydrate Chemistry i7 (Eds Whistler R.L. and Be Miller, J.N.) Academic Press New York. 
Ghanim, A. A. et al.

Ibrahim, M. M. (2005): Ecological and biological studies on persimmon (Diospyros kaki L.) pests and their natural enemies. Ph.D. Thesis, Fac. Agric. Mansoura Univ. pp. 154.

Jones, I.R.; Benton, I.; Wolf, B. and Mills, H.A. (1991). Plant analysis. Hand book, Methods of plant analysis and inter-predation. Micro-Macro. Publishing, inc., USA. P, 30-34.

Khalaf, J. (1987). Biological control of Icerya purchasi in Fars. Entomologieet-Phytopathologie-Appliquees, 54(2):123-128.

Lehan, R. (1998). Breadfruit pest succumbs to a ladybird beetle. Parteners in infesting persimmon- a new host record. Tropical-Pest-Management, 38(1): 107-108.

Matsuka, M. and Watanabe, M. (1981). Laboratory rearing of vedalia beetles Rodolia cardinalis. Bull. of the Faculty of Agriculture Tamagawa university, 20: 1-8.

Mousa, gehad M. (1992). Studies on certain coccinellid predatory insects at Mansoura district. M. Sc. Thesis, Fac. Agric., Mansoura Univ. pp. 122.

Ragab, M. E. (1995). Adaptation of Rodolia cardinalis (Mulsant) (Coleoptera: Coccinellidae) to Icerya aegyptiaca (Douglas) (Homoptera: Margarodidae) as compared with Icerya purchasi Mask. J. Appl. Ent., 119(9):621-623.

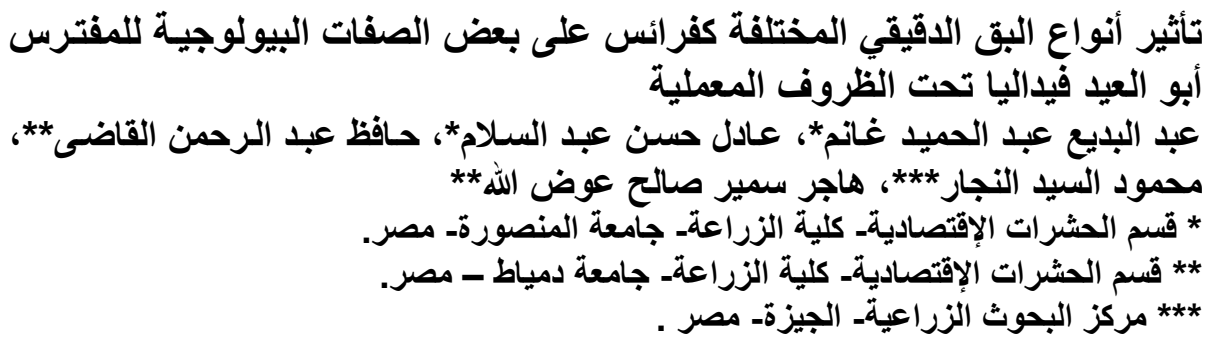

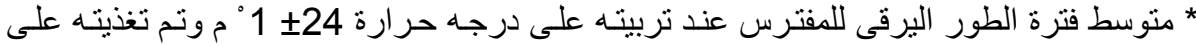

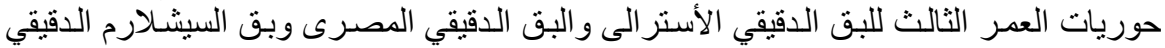

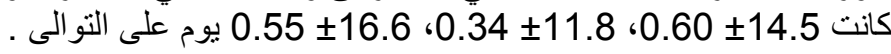

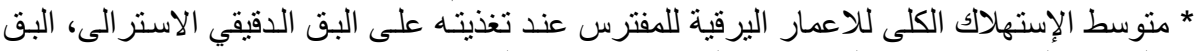

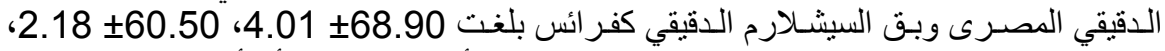

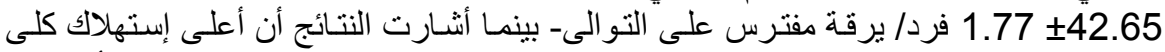

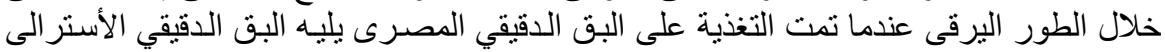

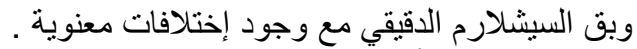

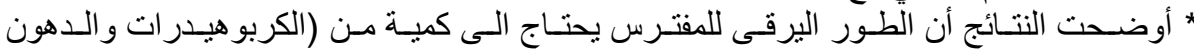

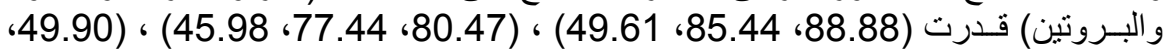

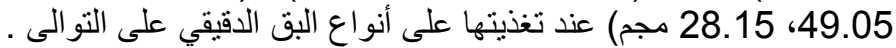

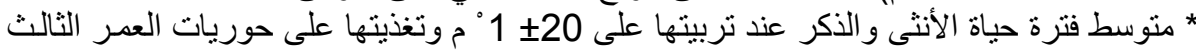
اللبق الدقيقي الأستر الىى، البق الدقيقي المصرى، بق السيشلارم الدقيقي أستغرقت (40.5ـ 2.25، 
26.8

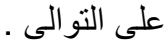

* منوسط الإستهلاك الكلى للانثى بلغت (263.2

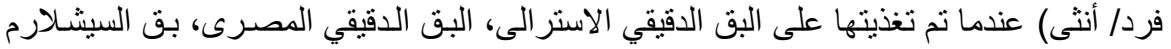

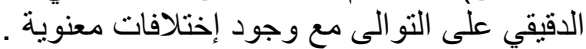

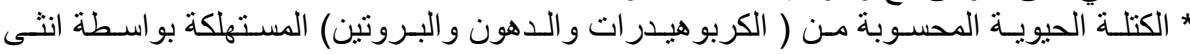

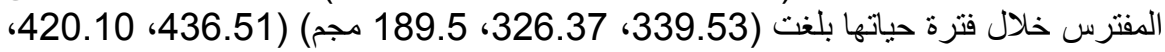

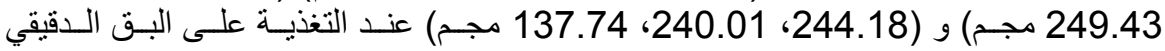

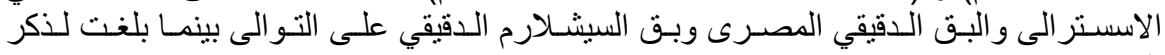

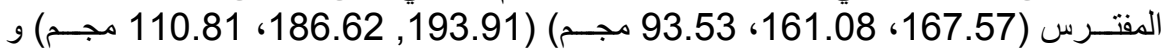

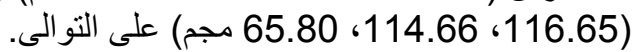

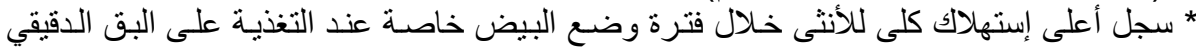

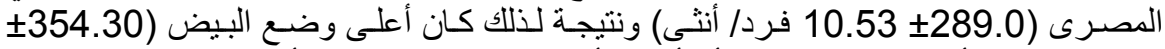

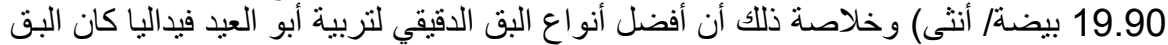
الدقيقي المصرى لأن الإناث وضعت 354.30 بيضة/أنثى.

كلية الزراعة - جامعة المنصورة مركز البحوث الزراعيه

$$
\text { قام بتحكيم البحث }
$$

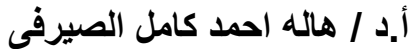
أ.د / محمود رمزى شريف أد الهيرف 